\title{
Rise of the machines
}

\author{
Navjoyt Ladher scholarly content editor
}

The BMJ

Computers replacing doctors may seem like science fiction, but our Feature this week on the potential of machine learning in healthcare suggests it is closer than we might think (doi:10.1136/ bmj.i5680). The Google owned company DeepMind is working with several NHS hospitals to develop a range of diagnostic tools. For this it needs (and has been given access to) patients' data, prompting questions about whether patient consent and public awareness have been adequate for a third party to use NHS records in this way. What assurances do we have that DeepMind won't share these data with its parent company? In response, DeepMind is reviewing its processes and seeking input from patients (http://bit.ly/2eNn292). We would welcome your views in a rapid response to this article.

Another technology changing the clinical encounter is the video camera. With news that body cameras worn by police reduce the number of complaints against officers, Margaret McCartney considers whether recording consultations might have a similar effect on complaints against healthcare staff and help patients remember what was said (doi:10.1136/bmj.i5674). But she cautions against unintended consequences. And how would recording affect the doctor-patient relationship, particularly if patients start covertly recording consultations?
Could technology be the key to greater awareness about climate change? The UK government is facing legal action over its breach of European Union air quality regulation, ${ }^{1}$ four in $10 \mathrm{UK}$ councils exceed air pollution limits, ${ }^{2}$ and a surge in the number of diesel cars on UK roads has set back progress on emissions and clean air zones. Against this backdrop, the UK Health Alliance on Climate Change launched its first report last week, calling for urgent action to tackle air pollution and climate change by reducing use of fossil fuels (doi:10.1136/bmj.i5621). As Frank Kelly explains in his Editorial (doi:10.1136/bmj. i5620), perhaps the answer lies with smartphones. As Kelly points out, apps that monitor air quality are increasingly raising public awareness. If they lead to political pressure, they may be just be the impetus we need for change.

LePage M. UK government taken to court over failure to cut air pollution. New Scientist 2016.www.newscientist.com/article/2109362-uk-government-taken-to-court-over-failureto-cut-air-pollution

2 Boffey D. Four in 10 UK councils exceed air pollution limits, figures show. Guardian Oct 2016. www.theguardian.com/environment/2016/oct/22/four-in-10-uk-councils-exceed-airpollution-limits-figures-show.

Published by the BMJ Publishing Group Limited. For permission to use (where not already granted under a licence) please go to http://group.bmj.com/group/rights-licensing/ permissions 